\title{
Cervical Cancer cT1b2 TNM Finding v7
}

National Cancer Institute

\section{Source}

National Cancer Institute. Cervical Cancer cT1b2 TNM Finding V7. NCI Thesaurus. Code C89486.

Invasive cervical cancer with clinically visible lesion more than $4.0 \mathrm{~cm}$ in greatest dimension confined to the cervix. (from AJCC 7th Ed.) 